\title{
Relationship Between Working Capital Management Efficiency and Profitability: A Comparative Study on Square Pharmaceuticals Limited and Beximco Pharmaceuticals Limited, in Bangladesh
}

\author{
Rejaul Karim ${ }^{1}$, Md. Abdullah Al-Mamun², Md. Tota Miah ${ }^{1}$ \\ ${ }^{1}$ Department of Business Administration, Varendra University, Rajshahi, Bangladesh \\ ${ }^{2}$ Department of Business Administration, Pabna University of Science and Technology, Pabna, Bangladesh
}

Email address:

rkarimreja@gmail.com (R. Karim),mamunfin38@yahoo.com (Md. A. Al-Mamun), totamgtru@gmail.com (Md. T. Miah)

To cite this article:

Rejaul Karim, Md. Abdullah Al-Mamun, Md. Tota Miah. Relationship Between Working Capital Management Efficiency and Profitability: A Comparative Study on Square Pharmaceuticals Limited and Beximco Pharmaceuticals Limited, in Bangladesh. International Journal of Economics, Finance and Management Sciences. Vol. 5, No. 2, 2017, pp. 121-128. doi: 10.11648/j.ijefm.20170502.16

Received: January 19, 2017; Accepted: February 10, 2017; Published: March 9, 2017

\begin{abstract}
Pharmaceutical is an important adjunct of industrialization in Bangladesh. This paper examines the effects of working capital management efficiency on the profitability of the two leading pharmaceuticals companies of Bangladesh Square Pharmaceuticals Limited (SPL) and Beximco Pharmaceuticals Limited (BPL) and to make a comparison of financial efficiency between these two firms. The secondary data for a period of ten years (2006-2015) have been analyzed by using correlation, t-test, and different profitability, liquidity and solvency ratios. The study reveals that there is a significant relationship between working capital management efficiency and profitability of both of the firms. The study also finds Square Pharmaceuticals Limited is more efficient in working capital management than Beximco Pharmaceuticals Limited. The financial performance of Beximco Pharmaceuticals Limited should be improved immediately through the efficient management of working capital to increase its profitability.
\end{abstract}

Keywords: Pharmaceuticals Industry, Profitability, Working Capital Management Efficiency, Bangladesh

\section{Introduction}

Working capital management has become very important in financial management because of its effects on the firm's profitability, risk and consequently the value of the firm. There are several important reasons why the management of working capital is important to both small and large organizations.

"A well designed and implemented working capital management policy is expected to contribute positively to the creation of a firm's value [1]". "Current assets of many companies, accounts for over half the total assets and are even higher in the companies in the distribution sector [2]".

However, a company is required to maintain a balance between liquidity and profitability while conducting it day to day operation. This required that a business must be run both efficiently and profitably. In the process,
Assets-liability miss-match may occur, which may increase the firm's profitability in the short-run but at a risk of its insolvency. On the other hand, too much focus on liquidity will be at the expense of profitability of the firm. "In addition, efficient WCM will allows firms to redeploy underutilized of firm's resources to higher-valued use in which could heightening of firm's performance [3]".

\section{Objectives of the Study}

The broad objective of the study is to examine effects of working capital management on the profitability of the pharmaceuticals industry in Bangladesh. The specific objectives of the study are:

i. To assess the relationship between working capital 
management and profitability of selected Pharmaceuticals companies.

ii. To have an overall idea about the efficiency of working capital management in pharmaceuticals industry in Bangladesh.

iii. To make comparisons between profitability of Square Pharmaceuticals Ltd. and Beximco Pharmaceuticals Ltd.

\section{Hypothesis of the Study}

To meet our prime objective of this study, we formulated to following hypothesis.

$H_{0}$ : Working capital management has no significant influence on the profitability.

$H_{1}$ : Working capital management has significant influence on the profitability.

\section{Literature Review}

Efficient management of working is the key area of financial management and plays a significant role in any industry. A number of researchers in home and abroad have conducted research on the subject of working capital and its various components. Review of some related previous research work has been carried out to make a clear idea about working capital management efficiency and its various components. The working capital meets the short-term financial requirements of a business enterprise. It is a trading capital, not retained in the business in a particular form for longer than a year. The money invested in it changes form and substance during the normal course of business operations. The need for maintaining an adequate working capital can hardly be questioned. Just as circulation of blood is very necessary in the human body to maintain life, the flow of funds is very necessary to maintain business. If it becomes weak, the business can hardly prosper and survive. Working capital starvation is generally credited as a major cause if not the major cause of small business failure in many developed and developing countries [4]. The success of a firm depends ultimately, on its ability to generate cash receipts in excess of disbursements.

Study done by Kasiran, Mohamad, and Chin, (2015) on working capital management efficiency of small and medium enterprises in Malaysia for the time period of year 2010 2013. The results reveal that the selected small medium enterprise company was less efficient in managing their working capital during this study period. They addressed results as alarming signals towards SME industry in Malaysia since inefficient management of working capital could become a major cause of SME failure [5].

Abbadi and Abbadi, (2013) examine the determinants of WC for Palestinian industrial firms. They used a sample of 11 industrial firms that are listed on the Palestine Securities Exchange for the time period of 2004 to 2011. Their model includes WC as the dependent variable, while there are some financial and economic variables, such as CCC, operating cash flow, leverage, firm size, return on assets, interest rate on loans, and economic growth rate, as independence variables. The study found that the CCC, return on assets and operating cash flow are significant determinants and positively related to the $\mathrm{WC}$, while leverage and firm size are significant but negatively related to the WC [6].

Salawu and Alao (2014) studied the factors determining the $\mathrm{WC}$ in the listed manufacturing firms in Nigeria for the periods 2000-2009. Various financial variables such as sales, purchases, inventory, creditors, debtors and total assets were extracted from the results showed that the significant factors determining WC included sales growth, size of the firm, gross domestic product, and leverage. The proportion of fixed assets to total assets and the net trading cycle also determined WC but were not significant at the 0.05 level. The second tendency is related to policy or approach of WC. Most of the following studies tested the association of policies such as aggressive, conservative, investment and financing policies and profitability and liquidity to determine which policy or approach prefers [7].

A study conducted by Akoto et al. (2013) on the relationship between working capital management practices and profitability of all the 13 listed manufacturing firms in Ghana for the period from 2005 to 2009 . The study used return on equity (ROE) as a proxy for profitability. The results revealed that there is a significantly negative relationship between profitability and accounts receivable days. However, he conclude that firms' cash conversion cycle (CCC), current asset ratio, size, and current asset turnover significantly positively influence the profitability [8].

Quayyum (2011) conducted a study on companies of cement industry listed in Dhaka stock Exchange (DSE) and found a significance relationship between the profitability indices and various liquidity indices as well as working capital components form data of the period from year 2005 to 2009 [9].

Azam and Haider (2011) conducted a study on Non-Financial Institutions listed in KSE-30 index which covers the period for the year 2001 to 2010. Their study reveals that there is a significance impact of working capital management on firms' performance and it is concluded that managers can increase value of shareholder and return on asset by reducing their inventory size, cash conversion cycle and net trading cycle. Increase in liquidity and time period to supplier will also lead firms' overall performances [10].

Generally, working capital refers to a company's investment in current assets - cash, short-term securities, accounts receivable and inventories. However, for the purposes of working capital management, the more descriptive term is net working capital, which refers to the current assets minus current liabilities, which are typically accounts payable and other obligations due within one year. It is also explained as follows: "Current assets, commonly called working capital, represent the portion of investment that circulates from one form to another in the ordinary conduct of business [11]". This idea embraces the recurring transaction from cash to inventories to receivables and back to cash. As cash substitutes, marketable securities are considered part of working capital. 
Filbeck and Krueger (2005), defined working capital management as "it is the difference between resources in cash or readily convertible into cash (Current assets) and organizational commitments for which cash soon will be required (current liabilities) [12]".

Lazaridis and Tryfonidis (2006) investigated relationship between working capital management and corporate profitability of listed companies in the Athens Stock Exchange. The results of the article showed that there was a statistically significant relationship between profitability and cash conversion cycle. Moreover managers could create profits for their companies by handling correctly the cash conversion cycle and keeping each different components (accounts receivables, accounts payables, inventory) to an optimum level [13].

Raheman and Naser, (2007) studied the effect of different variables of working capital management including the Average Collection Period, Inventory Turnover in Days, Average Payable Period, Cash Conversion Cycle and Current Ratio on the Net Operating Profitability of Pakistani Firms. By using Pearson's correlation and regression analysis he found that there was a strong negative relationship between variables of Working Capital Management and Profitability. He also finds that as the cash conversion cycle increases, it leads to decrease in profitability of the firm and managers can create a positive value for the shareholders by reducing the cash conversion cycle to a possible minimum level [14].

Extensive research works on working capital management have been done in both public and private sectors including Multinational Companies in Bangladesh. Sayaduzzaman in 2007 in his in-depth research article "Working Capital Management: A study on British American Tobacco Bangladesh Company Limited" mentions that the efficiency of working capital management of British American Tobacco Bangladesh Company Ltd. is highly satisfactory due to the positive cash inflows and planned approach in managing the major elements of working capital. He found that working capital management helps to maintain all around efficiency in operations [15].

Chowdhury and Amin (2007) have conducted an intensive research on working capital management practices in pharmaceutical companies listed in Dhaka Stock Exchange (DSE). They found in their study that pharmaceutical firms operating in Bangladesh deal efficiently with their liquidity preferences and investment criteria and this is due to the competitive nature of this industry [16].

Rahman, (2011) investigated the relationship between working capital management and profitability of DSE listed textile mills in Bangladesh conducted for time period of 2006-2008. In his empirical study he finds that profitability and Working Capital Management position of the Textiles Industry in Bangladesh are not satisfactory. The study also reveals that correlation exists between working capital management and profitability. The study brings to fore that
Working Capital Management has a positive impact on Profitability [17].

Afza and Nazir, (2007) studied the relationship among the aggressive/conservative working capital policies and profitability as well as risk of firms for 208 public limited companies listed at KSE for the period of 1998-2005. Their investigative results found the negative relationship between working capital policies and profitability [18], validating the findings of Carpenter and Johnson (1983) and found no significant relationship between the level of current assets and liabilities and risk of the firms [19].

Among all the problems of financial management, the problems of working capital management have probably been recognized as the most crucial one. It is because of the fact that working capital always helps a business concern to gain vitality and life strength and to maximize profit.

\section{Data Sources}

In order to meet the objectives of the study, data were collected from secondary sources mainly from audited financial report of the selected pharmaceuticals companies. The data were mainly collected from the secondary source covering ten years' (i.e., from 2006 to 2015) audited financial reports of the two sample companies - Square Pharmaceutical Limited and Beximco Pharmaceutical Limited.

\section{Research Methodology}

The study adopted the diagnostic research design. Diagnostic research tries to determine the association of the subject matter with something else (Kothari, 2004). We have used a correlative design to investigate the effect of working capital management on the profitability of the two pharmaceuticals company in Bangladesh.

The methodology of this study is to find out the dependency of profitability ratios over many other working capital components and liquidity positions i.e. on various ratios and conversion cycles. To cover the liquidity, profitability, and activity position, few ratios and conversion periods relating liquidity of the firm have been considered. And for the purpose of the analysis, t-test about Pearson's coefficient of correlation between working capital and profitability has been conducted. We have calculated some of important liquidity and profitability ratios to reveal the liquidity and profitability position of our two selected firms.

\section{Findings and Analysis}

In our comparative study, we have evaluated return on investment (ROI), return on equity (ROE), receivables collection period (RCP), inventory turnover period (ITP), accounts payable period (APP), and cash conversion cycle (CCC) of two selected firms. 
Table 1. Descriptive Statistics.

\begin{tabular}{|c|c|c|c|c|c|c|}
\hline & \multicolumn{6}{|c|}{ Square Pharmaceuticals Limited (SPL) } \\
\hline & ROI (\%) & ROE (\%) & RCP (days) & ITP (days) & APP (days) & CCC (days) \\
\hline Mean & 10.61 & 13.58 & 14.33 & 117.99 & 15.81 & 116.52 \\
\hline \multirow[t]{3}{*}{$\mathrm{CV}$} & 21.16 & 10.40 & 13.70 & 21.49 & 79.21 & 25.35 \\
\hline & \multicolumn{6}{|c|}{ Beximco Pharmaceuticals Limited (BPL) } \\
\hline & ROI (\%) & ROE (\%) & RCP (days) & ITP (days) & APP (days) & CCC (days) \\
\hline $\mathrm{SD}$ & 0.60 & 0.76 & 12.57 & 67.00 & 13.95 & 66.23 \\
\hline $\mathrm{CV}$ & 18.98 & 16.69 & 25.35 & 28.63 & 31.83 & 27.62 \\
\hline
\end{tabular}

Source: Analysis of Annual Reports of SPL and BPL of the Year 2006, 2007, 2008, 2009, 2010, 2011, 2012, 2013, 2014, and 2015

Table 1 shows the descriptive statistics of the collected variables. The difference between the mean of return on investment (ROI) of SPL and BPL is very large i.e. SPL has $10.61 \%$ and BPL has only $3.15 \%$. The table also shows a significance differences between ROEs of SPL and BPL having the value of $13.58 \%$ and $4.56 \%$. So, in the context of profitability SPL is more efficient to earn profit than BPL. The table also shows SPL has standard deviation (SD) of ROI is $2.24 \%$ and that of ROE $1.41 \%$ and BPL has SD of ROI is $0.60 \%$ and that of ROE is $0.76 \%$ which means SPL has more profitability with more variability of returns but BPL has less profitability and less variability of returns. In case of coefficient of variance $(\mathrm{CV})$ of SPL has $\mathrm{CV}$ of ROI is $21.16 \%$ and that of ROE of $10.40 \%$ and BPL has CV of ROI is $18.98 \%$ and that of ROE is $16.69 \%$. In our comparative study we see that receivables collection period (RCP) of SPL has significant lesser value of mean is 14.33 days with SD of 1.96 days and $\mathrm{CV}$ of 13.70 days than BPL with mean of 49.58 days, SD of 12.57 days and CV of 25.35 days. That means SPL has smooth and efficient policy to collect receivables within shortest period of time than BPL. The average time needed to convert raw-materials into finished product for SPL is 117.99 days and for BPL is 234.03 days, also SPL has smaller value of SD and CV than that of BPL which represents the efficiency of the management of SPL. The average APP of BPL is 43.83 days and that of SPL is only 15.81 days which indicates BPL takes more time pay its dues than that of SPL. But in case of cash conversion cycle (CCC), SPL has the mean of 116.52 days and BPL has the mean of 239.78 days which represents BPL requires less time to convert the cash into cash through the process. At last our fond result says that management of SPL is more efficient than that of BPL.

Pearson's Coefficient of Correlation between Working Capital and Profitability of the Firm:

Pearson's coefficient of correlation is the degree and type of relationship between any two or more quantities (variables) in which they vary together over a period. In the general sense of finance we see the inverse relationship between liquidity and firm's profitability i.e. the larger volume of working capital the lower profitability of the firm and vice-versa. Here ROI and ROE are treated as the indicator of profitability and RCP, ITP, APP and CCC are considered as indicators of liquiditythe efficiency of working capital management.
Table 2. Correlation table of SPL and BPL.

\begin{tabular}{|c|c|c|c|c|}
\hline & \multicolumn{4}{|c|}{ Square Pharmaceuticals Limited (SPL) } \\
\hline & RCP & ITP & APP & CCC \\
\hline ROI & 0.218 & -0.028 & 0.503 & -0.222 \\
\hline \multirow[t]{3}{*}{ ROE } & 0.548 & 0.235 & 0.500 & -0.26 \\
\hline & \multicolumn{4}{|c|}{ Beximco Pharmaceuticals Limited (BPL) } \\
\hline & $\mathrm{RCP}$ & ITP & APP & $\mathrm{CCC}$ \\
\hline ROI & -0.095 & -0.608 & -0.664 & -0.493 \\
\hline ROE & 0.003 & -0.423 & -0.461 & -0.330 \\
\hline
\end{tabular}

The Table 2 shows the correlations of Return on Investment (ROI) and Return on Equity with Receivables Collection Period (RCP), Inventory Turnover Period (ITP) Average Payment Period (APP) and Cash Conversion Cycle (CCC) of both of SPL and BPL. In the case of SPL we see the correlation of ROI with RCP is 0.218 which indicates very low positive and ROE with RCP is 0.548 indicates moderate positive correlation. In case of ITP we see mixed result that is ROI and ITP are very low negatively correlated with the value of -0.028 and ROE and ITP are very low positively correlated with the value of 0.235 . The correlation of APP with ROI is 0.503 which indicates moderate positive correlation between them and APP with ROE is also moderate positively correlated which is 0.500 . In the case of SPL, ROI and CCC are very low negatively correlated which is -0.222 and $\mathrm{ROE}$ and CCC are moderate positively correlated which indicates that the larger value of CCC the smaller amount of ROI and ROE.

In case of BPL we see mixed result in the correlation of RCP with ROI and ROE that the correlation between ROI and RCP is very low negative which is -0.095 and ROE and RCP are very low positively correlated which is 0.003 . The correlation between ITP and ROI is -0.608 means they are moderate negatively correlated and ROE and ITP are also low negatively correlated which is -0.423 . APP is negatively correlated with both of ROI and ROE. APP and ROI are moderate negatively correlated which is -0.664 and ROE and APP are low negatively correlated with the value of -0.461 . In the case BPL we see that $\mathrm{CCC}$ has negative correlation with both ROI and ROE. ROI and CCC are moderate negatively correlated with the value of -0.493 and $\mathrm{CCC}$ and $\mathrm{ROE}$ are also low negatively correlated with the value of -0.330 . Here, it also expresses that the larger value of the $\mathrm{CCC}$ smaller amount of ROI and ROE. 
Table 3. T-test for Equality of Means (Assumed equal variance).

\begin{tabular}{lllllll}
\hline & T- value & P-Value & Mean Difference & \multirow{2}{*}{ Std. Error Difference } & \multicolumn{2}{c}{ 95\% Confidence Interval of the Difference } \\
\cline { 5 - 7 } & & & & Lower & Upper \\
\hline ROI & 10.161 & 0.000 & 7.46207 & .73438 & 5.91921 & 9.00494 \\
ROE & 17.765 & 0.000 & 9.01491 & .50745 & 7.94880 & 10.08102 \\
RCP & -8.764 & 0.000 & -35.248 & 4.022 & -43.698 & -26.799 \\
ITP & -5.122 & 0.000 & -116.035 & 22.655 & -163.630 & -68.439 \\
APP & -4.727 & 0.000 & -28.018 & 5.928 & -40.471 & -15.564 \\
CCC & -5.375 & 0.000 & -123.266 & 22.933 & -171.447 & -75.085 \\
\hline
\end{tabular}

*At $5 \%$ level of significance

Above table 3 shows the t-test for measuring the mean differences of SPL and BPL of our selected variables. The table shows that t-value of ROI is 10.161 and P-value is 0.00 which indicates that the difference between means of ROI of SPL and BPL is significant at $0.00 \%$ which is below the significance level of 0.05 . Similarly the differences of the means of ROE, RCP, ITP, APP and CCC of SPL and BPL are statistically significant which represents two separate firms have different profitability capacity and different working capital management efficiency. As a result, we cannot accept our null hypothesis. It implies that a relation exists between working capital management efficiency and profitability of both firms and which is statistically significant.

\section{Ratio Analysis}

Profitability, liquidity and solvency ratios are calculated through the evaluation of the audited annual reports of the two sample firms - Square Pharmaceuticals Limited and Beximco Pharmaceuticals Limited for the ten years period of 2006 to 2015. As our attempt is to find out a comparative result of our two sample firms, we have gone through the comparative analysis of some important ratios i.e. profitability ratios, liquidity ratios, and solvency ratios.

\section{Liquidity Ratios}

The liquidity ratios measure the ability of an enterprise to meet its short-term obligations and reflect the short-term financial strength of an enterprise. Liquidity is a pre-requisite for the very survival of an enterprise.

Table 4. Liquidity Ratios of SPL and BPL.

\begin{tabular}{llllllllll}
\hline & \multicolumn{2}{l}{ Current Ratio } & \multicolumn{2}{l}{ Quick (Acid Test) Ratio } & \multicolumn{2}{l}{ Net Working Capital Ratio } & \multicolumn{4}{l}{ Current Assets to Fixed Assets } & Net Working Capital to Total Asset \\
\cline { 2 - 9 } & SPL & BPL & SPL & BPL & SPL & BPL & SPL & BPL & SPL \\
\hline Mean & 1.75 & 2.02 & 0.90 & 1.02 & 0.75 & 1.02 & 0.45 & 0.42 & 0.13 \\
SD & 0.53 & 0.65 & 0.34 & 0.58 & 0.53 & 0.53 & 0.16 & 0.09 & 0.14 \\
CV & 0.30 & 0.32 & 0.38 & 0.56 & 0.71 & 0.64 & 0.36 & 0.21 & 0.07 \\
\hline
\end{tabular}

Source: Analysis of Annual Reports of SPL and BPL of the Year 2006, 2007, 2008, 2009, 2010, 2011, 2012, 2013, 2014, and 2015

Table 4 shows that the average current ratio is $1.75: 1$ in SPL 2.02:1 in BPL. It is seen from the table that SPL has the current ratio below the norm (2:1) and BPL has the ratio above the norm and the differences in SDs and CVs are insignificance. Our calculation also shows that the average quick (or acid test) ratio is 0.90:1 in SPL and 1.02:1 in BPL. It is seen from the table that SPL has the quick ratio below the norm $(1: 1)$ and BPL has the ratio above the norm which signifies that SPL has an uncertainty to meet the short term obligations from its most liquid assets and BPL has sufficient most liquid assets to meet the short-term liabilities. But the differences in SDs and CVs are insignificant.

We also see in the table that BPL has a higher average ratio of net working capital ratio of 1.02:1 as compared with that of SPL of $0.75: 1$. SD of SPL and BPL is same of 0.53 and CV is also varies between these two firms where SPL with 0.71 and BPL with 0.64. The above table shows that the average ratio of current asset to fixed assets is $0.45: 1$ in SPL and0.42:1 in BPL. It is seen from the table that the ratios of current asset to fixed assets are very close to each other. SD of SPL is 0.08 and 0.05 in BPL; the CV of SPL is 0.19 and 0.10 in BPL. Our calculated table also shows that the net working capital to total assets ratios for the selected pharmaceuticals for the study period is 0.12:1 in SPL and which is 0.19:1 in BPL. SD for both of the firms is 0.03 and CV of SPL is 0.22 and BPL is 0.14 . From the calculated ratios it is seen that the ratio of net working capital to total assets of our two samples firms have insignificant difference.

\section{Profitability Ratios}

Profitability is a measure of efficiency. It also indicates public acceptance of the product and shows that the firm can produce competitively. The profitability ratios measure the performance of profit of an enterprise. In other words the profitability ratios are designed to provide answers to questions such as what is the rate of profit. The analysis of the profitability ratio is important for the shareholders, creditors, prospective investors, bankers and the government alike. For our comparative analysis between selected two sample pharmaceuticals - Square Pharmaceuticals Ltd. And Beximco Pharmaceuticals Ltd. We have analyzed Gross profit margin ratios, returns on investment, net profit margin ratios and operating profit ratios. 
Table 5. Profitability Ratios of SPL and BPL.

\begin{tabular}{|c|c|c|c|c|c|c|c|c|c|c|c|c|}
\hline & \multicolumn{2}{|c|}{$\begin{array}{l}\text { Gross Profit } \\
\text { Margin }\end{array}$} & \multicolumn{2}{|c|}{$\begin{array}{l}\text { Operating Profit } \\
\text { Margin }\end{array}$} & \multicolumn{2}{|c|}{ Net Profit Margin } & \multicolumn{2}{|c|}{$\begin{array}{l}\text { Return on Investment } \\
\text { (ROI) }\end{array}$} & \multicolumn{2}{|c|}{$\begin{array}{l}\text { Return on Equity } \\
\text { (ROE) }\end{array}$} & \multicolumn{2}{|c|}{$\begin{array}{l}\text { Return on Asset } \\
\text { (ROA) }\end{array}$} \\
\hline & SPL & BPL & SPL & BPL & SPL & BPL & SPL & BPL & SPL & SPL & BPL & SPL \\
\hline Mean & $36.69 \%$ & $46.43 \%$ & $19.54 \%$ & $22.35 \%$ & $16.36 \%$ & $13.63 \%$ & $10.61 \%$ & $3.15 \%$ & $13.58 \%$ & $4.56 \%$ & $10.61 \%$ & $3.12 \%$ \\
\hline SD & $0.91 \%$ & $2.62 \%$ & $2.89 \%$ & $2.38 \%$ & $1.56 \%$ & $1.72 \%$ & $2.24 \%$ & $0.60 \%$ & $1.41 \%$ & $0.76 \%$ & $2.24 \%$ & $0.60 \%$ \\
\hline $\mathrm{CV}$ & $2.49 \%$ & $5.64 \%$ & $14.79 \%$ & $10.64 \%$ & $9.57 \%$ & $12.62 \%$ & $21.16 \%$ & $18.98 \%$ & $10.41 \%$ & $16.69 \%$ & $21.16 \%$ & $19.18 \%$ \\
\hline
\end{tabular}

Source: Analysis of Annual Reports of SPL and BPL of the Year 2006, 2007, 2008, 2009, 2010, 2011, 2012, 2013, 2014, and 2015

Table 5 shows that BPL has the higher average gross profit margin of $46.43 \%$ than $36.69 \%$ of SPL over the study period. Standard deviation (SD) of gross profit of BPL is also higher, which is $2.62 \%$ than that of SPL of $0.91 \%$ and in case of coefficient of variance (CV), BPL also has significantly higher value of $5.64 \%$ than that of SPL which is $2.49 \%$. The results show that SPL has lower but stable and increasing trend in gross profit ratio than that of BPL. In the above table we see that the average operating profit margin of the SPL is $19.54 \%$ and that of BPL is $22.35 \%$. SD of BPL for the ten-year study period is $2.38 \%$ which is also lower than that of SPL which is $2.89 \%$ and in case of CV SPL also has higher value of $14.79 \%$ than that of SPL of $10.64 \%$. Our calculation also shows that the average net profit in SPL is $16.36 \%$ and in $\mathrm{BPL}$ it is $13.63 \%$. SD of BPL is $1.72 \%$ which is also insignificantly higher than that of SPL which is $1.56 \%$ and in case of CV BPL also has higher value of $12.62 \%$ than that of SPL of $9.57 \%$.

In the table it is also seen that the return on equity (ROE) of the sample pharmaceuticals for the study period the average ratio of SPL is significantly higher with $10.61 \%$ than that of BPL with only $3.15 \%$. SPL has also the higher SD which is $2.24 \%$ which in the BPL is $0.60 \%$ but in case of $\mathrm{CV}$, the differences is insignificant between two sample firms has. The average return on equity of SPL is $13.58 \%$ which is significantly higher than that of BPL which is only $3.15 \%$. From our calculated results and differences of mean, standard deviation and coefficient of variance it is observed that there is a significant difference in return on Shareholder' equity between SPL and BPL and which indicates SPL is also very efficient than BPL. The above table also shows that the average return on total assets (ROA) is $10.61 \%$ in SPL and $3.12 \%$ in BPL. SD of SPL is $2.24 \%$ and BPL is $0.60 \%$ and $\mathrm{CV}$ is also varies between these two firms where SPL has $21.16 \%$ and BPL with $19.18 \%$. From the above calculated table it is observed that there is significant difference in the averages of return on asset (ROA) between SPL and BPL which expresses that SPL is more efficient in managing the return on assets than BPL.

\section{Solvency Ratios}

Solvency of an organization represent the ability to meet its debts and other obligations within due time. The long-term solvency of a company is an important aspect to the present and future long-term creditors, banks, debenture holders etc. The long-run solvency of a company can be measured by the use of two important solvency ratios named debt to equity ratio and debt to total assets ratio.
Table 6. Solvency Ratios of SPL and BPL.

\begin{tabular}{lll}
\hline & Debt to Equity Ratio & \\
\cline { 2 - 3 } & SPL & BPL \\
\hline Mean & 0.36 & 0.46 \\
SD & 0.11 & 0.15 \\
CV & 0.30 & 0.34 \\
& Debt to Total Assets Ratio & \\
& SPL & BPL \\
Mean & 0.27 & 0.31 \\
SD & 0.07 & 0.06 \\
CV & 0.27 & 0.21 \\
\hline
\end{tabular}

Source: Analysis of Annual Reports of SPL and BPL of the Year 2006, 2007, 2008, 2009, 2010, 2011, 2012, 2013, 2014, and 2015

The table 6 shows the solvency ratios of our two sample firms for the ten-year study period. It is revealed from the table that the average debt-equity ratio in SPL is $0.36: 1$ and $0.46: 1$ in BPL. The standard deviation of SPL is 0.11 and that of BPL is 0.21 . The CV in SPL is 0.30 and 0.34 in BPL. The result shows that BPL has more debt proportionate to the equity capital as compared with SPL.

It is also observed from the table that the average debt to total assets ratio for the study period is $0.27: 1 \mathrm{in}$ SPL and that of BPL is $0.31: 1$. SD for SPL is. 07 and for BPL is 0.06 and CV of SPL is 0.27 and which 0.21 for BPL. The calculated ratios indicate the claim of creditors on total assets of BPL is higher than SPL with the proportionate to total assets. In case of SD and $\mathrm{CV}$ are also significantly differ from each other as BPL has the more value than SPL.

\section{Conclusion}

The present study attempt to analyze the effect of working capital management efficiency on the firms' profitability of selected pharmaceuticals firms - Square Pharmaceuticals Limited and Beximco Pharmaceuticals limited in Bangladesh. On the basis of our found result we can conclude that our study shows there is a significant relationship between these variables. The study also reveals that the financial position and operational performance of the Square Pharmaceuticals Limited is better and efficient than Beximco Pharmaceuticals Limited in about every cases of different ratios and various conversion period in production cycle in our ten-year study period. The inefficiency of financial management may be a major cause for such a poor position of BPL where the financial management of SPL shows very impressive records to manage working capital of the firm.

The followings are the recommendations from the 
researchers based on the findings of the study that can be taken into the consideration by managers to improve the performance of the pharmaceuticals firms.

I. The financial management department of BPL specially purchase, sales and inventory management have to be motivated, so that they act all the tasks cordially, efficiently and honestly.

II. The Pharmaceuticals firms should regularly make use of ratio analysis and measure should be taken to improve undesirable ratios at least as to the point of industry's average.

III. Qualified, trained and experienced management personnel should be appointed.

IV. Government regulations should be flexible and policy should be realistic.

V. Operational efficiency should be increased by reducing cost and wastage and improving operating and management performance. Supply of working capital should be adequate.

This study confined the analysis of data of only two firms of pharmaceuticals industry in Bangladesh. This is our main limitations of our study. A wider research in measuring the factors that might influence the efficiency of working capital management across a larger sample of pharmaceuticals companies in Bangladesh is very important.

Future research can be done to highlight this issues by taken into consideration a larger sample to represents a wider perspective towards working capital management efficiency in pharmaceuticals industry in Bangladesh particularly with a longer years observation. Thus this study is left for future to be further explore.

\section{Appendices}

Table A1. Variables of ratio analysis and the formulas used to calculate them.

\begin{tabular}{|c|c|c|}
\hline Sl. No. & Variables & Formula Used for Calculation \\
\hline \multicolumn{3}{|c|}{ Liquidity Ratios } \\
\hline 1. & Current Ratio & Current assets/ Current Liabilities \\
\hline 2. & Quick (or Acid Test) Ratio & Liquid assets (Quick assets)/ Current Liabilities \\
\hline 3. & Net Working Capital Ratio & Net working capital/ Current Liabilities \\
\hline 4. & Current Assets to Fixed Assets & Current assets/ Fixed assets \\
\hline 5. & Net Working Capital to Total Assets & Net Working Capital/ Total Assets \\
\hline \multicolumn{3}{|c|}{ Solvency Ratios } \\
\hline 6. & Debt-Equity Ratio & Total debt/Total Equity \\
\hline 7. & Debt to Total Assets Ratio & Total debt/ Total Assets \\
\hline \multicolumn{3}{|c|}{ Profitability Ratios } \\
\hline 8. & Gross Profit Margin & Gross Profit/Sales \\
\hline 9. & Net Profit Margin & Net Profit/Sales \\
\hline 10. & Operating Profit Ratio & Operating Profit/Sales \\
\hline 11. & Return on Equity (ROE) & Net profit/Average Equity \\
\hline 12. & Return on Asset (ROA) & Net profit/Average Assets \\
\hline \multicolumn{3}{|c|}{ Activity Ratios } \\
\hline 13. & Receivables Collection Period (RCP) & Credit Sales/Accounts Receivables \\
\hline 14. & Inventory Turnover Period (ITP) & Cost of Goods Sold/ Ave. Inventory \\
\hline 15. & Average Payable Period (APP) & Cost of Goods Sold/Accounts Payable \\
\hline 16. & Cash Conversion Cycle (CCC) & RCP+ITP-APP \\
\hline
\end{tabular}

Table A2. Result of Pearson's Coefficient of Correlation of our variables - ROI with RCP, ITP, APP and CCC of SPL.

\begin{tabular}{llll}
\hline & $\begin{array}{l}\text { Return on } \\
\text { Investment (ROI) }\end{array}$ & $\begin{array}{l}\text { Receivables Collection } \\
\text { Period (RCP) }\end{array}$ & $\begin{array}{l}\text { Inventory Turnover } \\
\text { Period (ITP, in days) }\end{array}$ \\
Return on Investment (ROI) & 1 & 1 & \\
Peceivables Collection Period (RCP) & .218 & .457 & 1 \\
Inventory Turnover Period (ITP, In days) & -.028 & .501 & -.076 \\
Average Payable Period (APP) & .503 & $-.978^{* *}$ & -.563 \\
Cash Conversion Cycle (CCC) & -.176 & -.454 \\
\hline
\end{tabular}

**. Pearson Correlation is significant at the 0.01 level (2-tailed), $\mathrm{N}=10$. 
Table A3. Result of Pearson's Coefficient of Correlation of our variables - ROI with RCP, ITP, APP and CCC of BPL.

\begin{tabular}{|c|c|c|c|c|c|}
\hline & $\begin{array}{l}\text { Return on } \\
\text { Investment (ROI) }\end{array}$ & $\begin{array}{l}\text { Receivables Collection } \\
\text { Period (RCP) }\end{array}$ & $\begin{array}{l}\text { Inventory Turnover } \\
\text { Period (ITP, In days) }\end{array}$ & $\begin{array}{l}\text { Average Payable } \\
\text { Period (APP) }\end{array}$ & $\begin{array}{l}\text { Cash Conversion } \\
\text { Cycle (CCC) }\end{array}$ \\
\hline Return on Investment (ROI) & 1 & & & & \\
\hline Receivables Collection Period (RCP) & .548 & 1 & & & \\
\hline Inventory Turnover Period (ITP, In days) & .235 & .457 & 1 & & \\
\hline Average Payable Period (APP) & .500 & .501 & -.076 & 1 & \\
\hline Cash Conversion Cycle (CCC) & -.529 & $-.978^{* *}$ & -.563 & -.454 & 1 \\
\hline
\end{tabular}

**.Pearson Correlation is significant at the 0.01 level (2-tailed), $\mathrm{N}=10$.

\section{References}

[1] Padachi, K., Howorth, C., Narasimhan, M. S., \& Durbarry, R. (2010). Working capital structure and financing pattern of Mauritian SMEs. Oxford Business \& Economics Conference Program, June 28-29, 2010, St. Hugh's College, Oxford University, Oxford, UK.

[2] Van Horne, J. C. and Wachowicz, J. M. (2004). Fundamentals of Financial Management, 12th Edition, Prentice Hall Publishers, New York.

[3] Aktas, N., Croci, E., \& Petmezas, D. (2015). Is working capital management value-enhancing? Evidence from firm performance and investments. Journal of Corporate Finance, 30, 98-113.

[4] Rafuse, M. E. (1996). Working capital management: an urgent need to refocus. Management Decision, 34 (2), 59-63.

[5] Kasiran, F. W., Mohamad, N. A., \& Chin, O. (2016). Working Capital Management Efficiency: A Study on the Small Medium Enterprise in Malaysia. Procedia Economics and Finance, 35, 297-303.

[6] Abbadi, S. M., \& Abbadi, R. T. (2012). The determinants of working capital requirements in Palestinian industrial corporations. International Journal of Economics and Finance, $5(1), 65$.

[7] Salawu, R. O., \& Alao, J. A. (2014). Determinants of working capital management: Case of Nigerian manufacturing firms. Journal of Economics and Sustainable Development, 5 (14), 49-56.

[8] Akoto, R. K., Vitor, D. A., Angmor, P. L. (2013), Working capital management and profitability: Evidence from Ghanaian listed manufacturing firms. Journal of Economics and International Finance, 5 (9), 373-379.

[9] Quayyum, S. T. (2011). Effects of working capital management and liquidity: evidence from the cement Industry of
Bangladesh. Journal of Business and Technology (Dhaka), 6 (1), 37-47.

[10] Azam, Dr. Muhammad, Haider, Syed Irfan (2011). Impact of Working Capital Management on Firms' Performance: Evidence from Non-Financial Institutions of KSE-30 index. Interdisciplinary Journal of Contemporary Research In Business, 3 (5).

[11] Gitman, L. J. (2009). Principles of Managerial Finance, 12th Edition, Pearson-Addison Wesley Publishers, New York.

[12] Filbeck, G., \& Krueger, T. M. (2005). An analysis of working capital management results across industries. American Journal of Business, 20 (2), 11-20.

[13] Lazaridis, I., \& Tryfonidis, D. (2006). Relationship between working capital management and profitability of listed companies in the Athens stock exchange.

[14] Raheman, A., \& Nasr, M. (2007). Working capital management and profitability-case of Pakistani firms. International review of business research papers, 3 (1), 279-300.

[15] Sayaduzzaman, M. D. (2007). Working Capital Management: A Study on British American Tobacco Bangladesh Company Ltd. Journal of Nepalese Business Studies, 3 (1), 78-84.

[16] Chowdhury, A., \& Amin, M. M. (2007). Working capital management practiced in Pharmaceutical companies in Dhaka stock. BRAC University Journal, Vol. IV, No. 2, 2007, pp. 75-86.

[17] Rahman, M. M. (2011). Working capital management and profitability: a study on textiles industry. ASA University Review, 5 (1), 115-132.

[18] Afza, T., \& Nazir, M. S. (2007). Is it better to be aggressive or conservative in managing working capital. Journal of quality and technology management, 3 (2), 11-21.

[19] Carpenter, M. D., \& Johnson, K. H. (1983). The association between working capital policy and operating risk. Financial Review, 18 (3), 106-106. 